\title{
Community Transitions to Low Carbon Futures in the Transition Towns Network (TTN)
}

\author{
Gerald Aiken*
}

Department of Geography, Durham University

\begin{abstract}
This paper examines the use of 'community' rhetoric in the Transition Town Network (TTN). This is seen in both its external and internal context. Externally, TTN has emerged against the backdrop of an increasing use of 'community' rhetoric in environmental governance, for example, in renewable energy projects. Internally, the use of 'community' language and 'community' ways of operating are crucial for understanding this movement, in how it sees itself and the lineage it builds upon. Particularly, TTN builds upon the polysemic, subjective nature of the word, fused with their unique permaculture inspired meaning. TTN have emerged as an important response to climate change and peak oil (Bailey et al. 2010; Mason and Whitehead 2011). This paper attempts to address their crucial, if neglected, focus on 'community'. In the wide sweep of writing on 'community', what distinctive, if anything, can TTN add to current understandings and practices of 'community'?
\end{abstract}

\section{The Use of Community in UK Environmental Governance}

First, this article addresses the background rhetoric of 'community' in the UK, from which Transition Town Network (TTN) ${ }^{1}$ have emerged. This is important to frame the funding and policy contexts, which have impacted the spread and development of TTN. A recent review of 'community' renewable energy projects in the UK they concluded that the "community' label was "much used", and is "one that continually proved difficult to pin down" (Walker and Devine-Wright 2008, 497). Aware of this, three possible reasons for the wide and increasing use in 'community' rhetoric, in UK environmental governance, are set out below:

1 attempting buy-in from local residents,

2 specifying the scale at which transitioning to low carbon futures operate, and,

3 reflecting a bottom-up, grassroots emergent response.

\subsection{SUBJECTIVE BUY-IN}

The first reason to explain the rise in 'community' responses to climate change is that such language helps generate buy-in from local residents. The 'community' label varies in use: from projects owned and managed by local residents, to those being branded by 'outside' developers as a way to assuage local opposition, and a full spectrum in between (Walker and Devine-Wright 2008). The attraction of using 'community' rhetoric is that it can be a useful tool in attempting to see off potential objections from local residents to any new project. Community has long been used as a "warmly persuasive word" that is "never used unfavourably" (Williams 1983, 76), and can be adopted by energy companies as a positive label to be associated with and help in attempts to pre-empt potential 
objections, NIMBY or otherwise, to developers plans (Toke et al. 2008; Warren and McFadyen 2010).

The community 'branding' can make such schemes much more appealing. DevineWright (2005) and Toke (2005) both argue that a shift to local ownership of wind farms results in higher levels of acceptance, local support and equity. Warren and Birnie (2009) outline how potential conflict over renewable energy schemes are not so much arguments over facts, but "whether they and their community had a personal stake in their development"; this was down to no more than a "subjective 'sense of ownership'" that the 'community' branding or labelling has associations of $(2009,117)$. This subjective sense is crucial here, as the 'community' label still retains the positive perception whether or not the project is owned invests their profits locally (such as Berwick's Community Wind Turbine). ${ }^{2}$ Many of the words relevant to this topic have been seen as subjective, which has perhaps been key to their rise and adoption by a wide variety of stakeholders. One such "fuzzy" term - sustainability - has even been described as an "inherently vague concept" (Phillis and Andriantiatsaholiniaina 2001).

\subsection{COMMUNITY SCALE}

The second reason for the increase in community rhetoric refers to the scale that action on environmental issues requires. This scale has two dimensions. First, 'community' is seen as a level that exists somewhere between the micro (or, individual) level, and the macro (governments and corporations). The community here is the meso-scale between these two. The second scalar dimension to the use of the term community is where it becomes elided with notions of the local, a local community.

\subsubsection{Meso-level}

Previous attempts to frame responses to climate change have focused on the level of the individual (Hinchcliffe 1996). Most notable here is the personal carbon footprint, but there is also a strong discourse on the behaviour change of individuals that operates on a level akin to personal virtue. Barr and Gilg (2007) outline the theoretical and policy reliance on "individuals as the key agents of change" (2007, 361) towards any low carbon future. Recently, popular 'nudge' thinking sees the site of low carbon transition as individual choice (Thaler and Sunstein 2009). Community projects tend to eschew such thinking, rejecting market-mediation, or viewing individuals out of their surrounding context. Community is here a rejection of purely individual notions of agency and responsibility - but neither is it a return to structural determinism or that low carbon transitions need to be directed from 'above', through governments or corporations. The rise of 'community' is part explained by a redressing of this balance by addressing at a meso-level, both action and responsibility between supra-individual agencies and an individualist approach.

'Community' as an in-between scale does not fully do justice to the altogether different nature of acting as a collective, rather than as a group of individuals. For example, projects such as those that seek to gather together groups of individuals who want to install solar panels, in order to gain economies of scale discount on price, fall short of what is meant by 'community' here; that would be an individual approach, albeit on a larger scale. Community can be seen as a scale up from individual, but it is also a different category from other 'meta-individual' concepts, such as the 'group'. Heiskanen et al. (2010) conflates the individual with the consumer, counterpoised to this members of communities are 'citizens'. Here, belonging to a community response to climate change is seen as 
a rejection of a market mediation of one's relations with others, or even one's relationship to the surrounding environment. Working in a community such as this helps keep one 'on track', acting as a sort of ego-corrective against the draw of ecologically destructive socio-cultural norms, in a way that being part of a group doesn't.

A concerted critique of individualism, or reduction of environmental responsibilities to the individual/consumer, provides a fertile ground out of which radical collectives (or even a discourse of 'community') can emerge. "There is a rather direct relationship between individual and collective modes of co-ordination, a decline in one almost always leads to an increase in the other" (Shove 2003, 180). In this sense the use of community is better defined by what it is not - it is not individual. But it is not a high-level structure either. Hinchcliffe (1996, 61) critiques the "focus upon a single, rather abstract, scientific hypothesis reproduced the notion that environmental problems were the responsibility of distant and equally abstract institutions". Community here serves as a middle way between individualism and supraindividual agencies (governments/corporations).

\subsubsection{Local community}

Walker et al. (2007, 17) again repeats the "diversity of ways in which the 'community' label has been utilised" in environmental policy. Despite this, one continual motif throughout this literature though is the way in which community is used as a synonym for the local. Amin (2005) terms this the elision between local and community.

When the UK government released its Low Carbon Transition Plan, a major section was given over to role 'communities and homes' would play in future energy policy (2009, 77-110). Here, the local community is primarily a concept of scale. These responses are local and desired in addition to overarching policy initiatives, but the fusing of 'community' and 'local responses' are typical. The local response gains more appeal with the very public failure of high-level discussions on carbon reduction, most prominently the Kyoto Protocol and COP 15. Seeing community as local, retains a strong assumption that communities are rooted in particular places - locations. This is adopted by TTN initiatives, but their sense of local goes beyond the concept of communities of place, as often contrasted with communities of interest. Often these TTN community initiatives retain aspects of both communities of place and interest, as seen in Section 2.

\subsection{COMMUNITY AS GRASSROOTS COLLECTIVES}

Thirdly, 'community' has been used in environmental governance to refer to a grassroots, bottom-up response. If the above uses are projecting a concept of 'community' onto a given project, area or group, this refers to the endogenous, inside-out, bottom-up 'community'. The concept of community projects in response to environmental concerns has a long grassroots history. For Seyfang $(2009$, 64), grassroots responses are "networks of activists and organisations generating novel bottom-up solutions ... solutions that respond to the local situation and the interests and values of the communities involved"'. Recently Middlemiss and Parrish also described how "grassroots initiatives for change" (2010, 7559) are inherently tied up with 'community'. Community here is seen as a "space for realising pro-environmental change" (2010, 7559). Community movements are not only local enough to be realisable and tangible. They are also emergent, ground-up activism. The community scale is local, but its movement is centripetal and sensitive to the needs of its local context. Community action then is particular, not a one-size-fits-all solution. More zuhanden than vorhanden; it is local, but just as much lived (Bauman 2001, 10). 
These three characteristics are by no means exhaustive, but are all present and helpful in explaining the rise and character of 'community' responses to climate change and for low carbon futures. TTN, a particularly prominent example of the rise of 'community' responses, contains all three aspects in their practice. They are appealing to local government and established political actors, by eschewing words like activist for an appealing umbrella term like 'community'. They attempt to focus on 'local resilience' and local relevance, by shortening feedback loops. They also wish to build on the grassroots legacy, building a coalition of other green groups. It is to their specific, internal, use of community that we now turn.

\section{Transition Town Network, and the Importance of 'Community' Therein}

The TTN emerged from Totnes, Devon in 2005. It drew on Rob Hopkins' prior experience as a permaculture teacher in Kinsale, Ireland. TTN was firmly rooted in permaculture principles from its inception. TTN's role is to support and facilitate growth in TTN groups. The first of these groups was Transition Town Totnes, and there are now 325 participating initatives across the UK and Ireland and its spread also extends to the USA, Australia, Canada and continental Europe. ${ }^{3}$ This prodigious rise in scope can be set in context of an increasing awareness of the issues concerning TTN (both climate change and peak oil) and also set against the relatively small scale/scope such fragmentary ventures have.

TTN describe themselves as a "community-led response to the pressures of climate change, fossil fuel depletion". " From the beginning TTN used permaculture, linked with Resilience Thinking (Walker and Salt 2006) in their approach to socio-ecological systems, of which community is a core expression (Mollison 1988). It is from this literature that their particular form of political mobilisation or activism takes root. For TTN they retain the subjective umbrella nature of 'community', its local specificity and grassroots heritage, but they also build on their permaculture heritage with a specific, more particular, meaning to 'community'.

TTN is based on permaculture, and it is not just Hopkins who has brought his permaculture background to TTN, many of those most involved in TTN initiatives have a background in permaculture, or are cultivating it (Connors and McDonald 2010). The key concepts incorporated into TTN thinking (resilience, transition and community) have been adopted from a permaculture approach (Holmgren 2011). Hopkins describes TTN as being "rooted in permaculture design", and endorses Holmgren's book "as a work of great genius" (2011, back cover). Permaculture can be understood as TTN's philosophical basis. Holmgren adopts a working definition of permaculture to be "consciously designed landscapes which mimic the patterns and relationships found in nature" (2011, xix). Thus, 'community' is read off the ecological realm and applied as a normative ideal to the social. Accordingly in permaculture, communities have been "deliberately planned or designed by their participants, rather than unconsciously evolved by social and economic processes" $(2011,174)$, they are holistic enough to be "spiritually based" and "would be regarded as utopian" (2011, 174). The given ideal 'community' based on permaculture is the kibbutzes founded in Israel after 1948. This case study is influential on TTN, but guides can be found in others such as the bioregional movement or the back-to-the-land movement (Smith 2005). This is foundational to how TTN envisions and plans 'community', but this specific permaculture meaning is fused with the plastic, polysemic nature of the word - the subjective, umbrella use described above.

'Transition' is a temporal term, it evokes change, movement, and flow, in keeping with TTN's permaculture base. However, there is less emphasis on the rate of this 
change; in this way, TTN can appeal to a broad spectrum of both reformers and revolutionaries in seeing the shift to a low carbon future. This is important for TTN, framing themselves as inaugurating a broad coalition of people and interests for the good of 'the whole community'. Similar words could be used but are eschewed, such as activist or radical, presumably for their divisive potential.

Both 'transition' and 'resilience' are key conceptual underpinnings for TTN. Yet it is 'community' that is just as central a concept, perhaps even the key motif throughout this movement. TTN initiatives are 'community-led'. Their chief end is a transition to achieving 'community resilience', not abstract, though important, foci such as cutting carbon emissions or enhancing energy security. For each initiative that springs up, the understanding is that TTN spreads as a contagion, emerging reactively to serve the needs of any given - again - community. Here, reacting to concerns over climate change and peak oil. Ben Brangwyn, co-founder of the TTN wrote a pithy phrase that has become something of a rallying cry:

If we wait for governments, it'll be too little, too late. If we act as individuals, it'll be too little. But if we act as communities, it might be just enough, just in time. ${ }^{5}$

So community is crucial for TTN. Not only is it the destination of the transition, it is the means of action by which they get there.

The recognition of 'community' as a central value in TTN comes not only from inside the movement, but also from outside. Smith $(2011,101)$ sees the "overriding grand-narrative" of TTN groups as "galvanising community", in the face of oil addiction and climate change. The popular press also buys into this rhetoric, where TTN's aim is "to move us 'from oil dependency to local resilience', using the power of community". (Irvine 2009, 19). So, TTN has community as a central focus and mobilising notion. It is not new to say that 'community' has been a contested term though. What more specifically do TTN groups mean when they invoke this concept of 'community' then?

First, as seen in the above aphorism, community is seen as the alternative and anti-dote to individualism. Community here refers to working together as a group - a collective. Not only is this seen as being more effective - in the manner of the whole being greater than the sum of the parts - but also moves away from the way in which environmental responsibilities and agency have been constructed. Talk of carbon footprints, appeals to saving money, or 'do a little, save a lot' styles of approach; these target the individual as the unit of analysis. The alternative to this, projecting blame onto to corporations and governments, is seen as equivalent to hiding one's head in the sand. Community here is the meso-layer that is effective.

Second, there is a strong link between TTN's 'communities' and location. This production of place is emphasized in the naming of the initiatives. There are exceptions (such as Transition Edinburgh University, or some of TTN's 'Heart and Soul' groups), but on the whole TTN refers to a community contained within a specific territorial boundary, be it a town (Totnes), a neighbourhood (Brixton) or local area (Transition North Howe). This place-base is emphasised by the focus on local responses. Here, the groups become communities of interest, within a particular place. Due to the common aim, TTN's volunteers share a community of interest, yet the focus in on transitioning a particular place. TTN's community here is not just an elision between local and community (Amin 2005), but also between communities of place and interest.

Linked to this point is the scalar nature of community that TTN envisions. This is relatively small, usually around the size of a small English market town (c. 10,000 people), such as Totnes. When the TTN model was adopted in larger urban settings this 
scalar dimension has generally been retained, focusing on specific neighbourhoods. In Edinburgh, for example, an attempt at a citywide TTN initiative was undertaken, before balking at the size of such a task, and the fragmenting into specific neighbourhood scale TTN cells within the city.

There is also a more subtle and subjective use of 'community', by TTN initatives, within the longstanding tradition suggesting the feeling the term evokes is as valuable as the meaning it contains. Recently, 'community' was described as a 'god word', due to its "appeal, rarely questioned and frequently invoked to legitimize what's done in its name". (Herbert 2010, 379). This subjective aspect to 'community' is certainly another reason for its appeal and perhaps for the success of TTN as a movement. However, teasing apart just how important, and in what specific ways can be difficult to unravel.

\section{Criticisms of TTN and Community}

\subsection{CRITIQUING COMMUNITY}

The TTN movement, initially flourishing in small towns such as Totnes, has migrated to larger urban environments. It is still wrestling with working out how the 'community' it talks about is manifest and realised in such contexts. What is interesting, against this background, is that the TTN, both reflects this rise in 'community' rhetoric in environmental governance, but is also united with it in criticisms of community as a concept, much of it tied to its urban expression.

Community as a concept has a long and contested history. Regularly traced back to Tönnies (1955) as a synonym for family, or intimacy. Subsequent writers have indicated that as a concept it was preoccupied with reified visions of what community was and ought to be (Bauman 2001; Crow and Allen 1994). One of the most well known, and criticised, is Willmott and Young's (1957) study of the East End of London. Here, genuine community was a 'good thing' and more likely to exist in rural, homogenous, well-off locations. The object of Willmott and Young's study - socially deprived East End of London - offered a dystopic vision of where community was headed. Community has continued to be debated since, but these normative uses and criticisms of community are still found. So we can add to the community characteristics of homogeneity, rurality, and affluence, a temporal displacement - either yearning for these things to come, or harking back to a bygone age (Defilipps et al. 2006).

These criticisms have a long legacy, but show no signs of going away. Morton (2010) recently pointed out that community implies homogeneity and reification through setting up arbitrary in/out boundaries, based, often, on territorial location. "The discourse of community ... is intrinsically conservative, if not reactionary, if not, at times, fascist" (2010, 208). Community as intrinsically fascist by no means reflects the view of community projects in environmental governance, and not in its use either. But what is interesting in extreme criticisms such as this is that these major threads in the literature on 'community' begin to look very similar to current critiques of TTN.

\subsection{CRITIQUING TTN}

The standard critique of TTN has focused on their being apolitical; a small, self-selecting, homogenous group - much as criticisms of 'community' in general have been seen. Perhaps, the most well-known evaluation has been the Trapese Collective's report, Rocky Road to a Real Transition (2008). Both the Trapese Collective and key figures within the 
Transition movement have kept up a healthy dialogue, but Trapese still points out that TTN avoids long established forms of political action, such as direct action or confronting interests of power directly. TTN as a movement neglects engaging in what they see as a more 'confrontational' politics, advocated by those like Trapese.

In his initial response to the Trapese report, a 'blog posting by Rob Hopkins defended the TTN emphasis on welcoming all comers. "Transition should appeal as much to the rotary $c l u b$ and the Women's institute as to the authors of this report". ${ }^{6}$ TTN presents itself as proleptically enacting a 'community' that welcomes all-comers, but there is less recognition that 'community' necessitates a boundary. Even if this boundary is not - following Morton fascist, there will be power and exclusion at play. Early in the TTN's emergence, there was a storyline on BBC Radio 4's The Archers, talking of the potential for a Transition Town to be started in the village where the soap opera is set - Ambridge. Understandably, given the publicity boon for an emerging movement, this was often mentioned by those in the TTN. However, being mentioned on the Archers did nothing to assuage concern that this was becoming Radio 4 activism: rural, middle-class and wrapped up with particular reified visions of community.

TTN then have had these same criticisms leveled as the concept of community: being overly rural, middle-class and lacking in diversity (in ethnicity or educational background) (Trapese Collective, 2008). The point to note here that TTN groups and one of their central concepts (community) should share such similar journeys, in praise and criticism, both in practice and theory.

\section{The Particular TTN View of Community}

TTN reflects all three of the ways in which 'community' has been used in environmental governance: generating local acceptance, a local, meso-scale approach, and one that builds on a grassroots legacy. However, for TTN, community's value is not to be found wholly in the use or meaning of the term. Part of this is its value as a mobilising, progressive force, which can be seen in its permaculture heritage. This 'community' requires intentionality and arises out of a focus on a common task.

For TTN the Permaculture approach - much related to complex systems thinking (Johnson 2000) - can be baptised from the ecological into the social realm. Although this description would be an anathema, as neither the social nor ecological realms exist independent of each other according to this approach, nature and culture seen as one continuous and unified process. Adopting this approach from plant communities, each 'community' is seen as both independent and interacting with others. It is both separate from and bound to its neighbouring community. Each 'community' works on and in a different place or scale. These are enmeshed within each other, overlapping and nested. TTN's goal of resilience will only be achieved, they see it, when our local communities are both independent and interacting - again a coalescence of means and end.

This is enacted in the TTN model in two ways: Open Space Technology and the Law of Two Feet (Hopkins 2008, 168). Open Space Technology involves four principles: whoever comes are the right people, whatever happens is the only thing that could have, whenever it starts is the right time, and when it's over it's over. The Law of Two Feet states that when you find yourself not being useful, you take your two feet and go somewhere where you can offer something. This is a model of community that is flexiform, shapeshifting and never permanent. It is rooted locally, based on small-scale personal interactions, but has swings and ebbs and flows of people, ideas and energy throughout. In short, everything exists in a permanent state of transition. 
It is here that the 'sense of community' that TTN seeks to engender can be recognised. It is a vision where the community is an active causal agent of the transition. It retains the place-base, grassroots and local legacies, but it is also something that doesn't just happen passively to a particular place or group of people. It is actively worked for, and requires time, attention to detail and commitment.

Community here is active rather than passive. TTN here can be seen against the backdrop of a wider shift in the use of 'community' in environmental governance; this is perhaps one reason for its significant rise in attracting funding. But there is also another separate lineage for transition and the use of 'community', which cannot be wholly understood by looking at environmental governance trends itself - but by recognition of the resilient, permaculture base. Rather than being apolitical as Trapese Collective and others suggest, TTN can be understood as creating an alternative politics, one that is not concerned with voting or other 'rituals of the State' (Badiou 2008, 11-12). Rather they "proactively create alternatives and produce immediate forms of action, often fuelled by a frustration with the slowness and inadequacy of existing responses" (Bulkeley and Newell 2010, 83). These "new collective assemblages of enunciation are beginning to form an identity out of fragmentary ventures, at times risky initiatives, trial and error experiments; different ways of seeing and of making the world" (Guattari 1995, 120).

It is not that the previous uses of community are not to be found in the TTN model, but that in themselves these are incomplete. For TTN, at times it can sound like 'community' is a synonym for area, or locale; on other occasions replaceable by movement, or collective. These are there, but at times it is more helpful to see 'community', for TTN, as also having synonyms such as Res Publica, or autopoeisis. These offer that different, proactive, borderless self-organisation vision of community. No doubt, this is easier to outline in theory than when the rubber hits the road and power struggles take root, and TTN are still a relatively new movement. Yet it is important to acknowledge the vision of community as inherently reflecting of each TTN group's particular location.

\subsection{DIVERSITY AND COMMUNITY IN TTN}

With this in mind, one possible reason for the select group that get involved in TTN groups - and the criticisms of exclusive in/out boundaries that follow - might be found in a recent report that describes a 'civic core' of the population (Mohan 2011). Members of this 'civic core' give disproportionally to charity or volunteer. These people tend to be middle-aged, well educated and live in prosperous areas. They are well resourced financially, educationally and with time - and are also more likely to be women, and also more likely to be involved with a faith-based community. This maps on incredibly well to the profile of those who tend to constitute TTN groups, and with the permaculture vision of community. It makes sense that this particular demographic would work towards kibbutz-style community outlined above. Given this, it is not surprising that TTN will attract those who tend to volunteer, or those with the resources to be able to volunteer. TTN seems to emerge - or is more likely to emerge - where the 'civic core' is more populous and prominent. This is not to dismiss TTN's issues with diversity, but inherent to the very movement, given its permaculture base, are rules, like the Law of Two Feet. These will necessarily attract those more used to using their feet - the more mobile members of society who are prone to volunteering.

A recent study of inclusion and diversity within TTN found flaws with the TTN model, despite the movement's rapid growth (Cohen 2010). For all TTN's focus on rhetoric of 'community' and being inclusive, it found them to appeal to a narrow section 
of the population. Following Lichterman (1995), this was put partly down to a vision of community that, while emphasising inclusivity, also wanted to empower individuals through this community. This, it was argued, appealed more readily and was more accessible to a specific subset of the population, those who were, broadly, more educated and well resourced. TTN have an inclusive understanding and, although this is not realised in full yet, have not shirked conversation with their detractors, as evidenced by their continued conversation with the Trapese Collective.

\section{Conclusion}

The TTN movement reflects the wider environmental governance context it sits in, when it uses community narratives and rhetoric. But it also has a quite different legacy it builds on: that of its permaculture heritage. For all the place-specific nature of the 'community' TTN talks about, its own sense of the word is indelibly marked by its own particular context, and history of those who make up and are attracted to the movement.

This is not to say this version of 'community' is free from criticism. Rather critiques of the apolitical and homogenous nature of TTN cells should recognise the rather different nature of TTN's 'community'. By talking of an autopoesis, fully emergent, locally specific nature of the groups, an analysis must look to the geography of the movement. This means not only looking to the scale that 'community' operates on, nor the wider environment in which TTN has emerged. But also the spatial distribution, and place-based specifics of each example. Such a geographic analysis requires looking at difference, for example, the difference between the resources (time, wealth, education, class) that those who get involved with the movement have and those who don't.

Community of place has been critiqued, and many different 'communities of X' (place, interest, practice, work, etc.) examples have followed. For TTN though, the most useful 'communities of X' typology is what Massey (2007) calls, communities of place beyond place. For TTN does not seek to overturn or move away from prior uses of community, but through their permaculture perspective, adds a new subtle twist. It is this going beyond, or delving deeper, that needs to be understood about TTN's relationship to and use of community.

\section{Short Biography}

Gerald Aiken is a postgraduate researcher in the Department of Geography, Durham University. He is currently working on his $\mathrm{PhD}$, funded by the ESRC, investigating the role of community in the UK's transition to low carbon futures. In 2011, he was the Manfred Heindler Research Fellow at the Institute for Advanced Studies in Science, Technology and Society (IAS-STS), in Graz, Austria. He has degrees from University of St Andrews, Durham and the Centre for Human Ecology (CHE). He is also a Resident Tutor at St. John's College, Durham, and a member of the Iona Community.

\footnotetext{
Notes

* Correspondence address: Gerald Aiken, Department of Geography, Durham University, Science Site, South Road, Durham City, County Durham DH1 3LE, UK. E-mail: gerald.aiken@durham.ac.uk.

1 These go under many different names: Transition Towns, Transition Initiatives, Transition Movement and Transition Culture are all used. TTN is preferred here as it allows conceiving of the movement as a whole, while recognising it is made up of separate, distinct initiatives.
} 
2 http://www.corecoop.net/ (Accessed 17/8/2011).

3 http://www.transitionnetwork.org/ (Accessed 17/8/2011).

4 http://www.transitionnetwork.org/ (Accessed 17/8/2011).

5 http://www.transitionnetwork.org/support/what-transition-initiative (Accessed 17/8/2011).

6 http://transitionculture.org/2008/05/15/the-rocky-road-to-a-real-transition-by-paul-chatterton-and-alice-cutlera-review/ (Accessed 17/8/2011).

\section{References}

Amin, A. (2005). Local community on trial. Economy and Society 34 (4), pp. 612-633.

Badiou, A. (2008). The meaning of Sarkozy. London: Verso.

Bailey, I., Hopkins, R. and Wilson, G. (2010). Some things old, some things new: the spatial representations and politics of change of the peak oil relocalisation movement. Geoforum 41 (4), pp. 595-605.

Barr, S. and Gilg, A. (2007). A conceptual framework for understanding and analyzing attitudes towards environmental behaviour. Geografiska Annaler B 89 (4), pp. 361-379.

Bauman, Z. (2001). Community: seeking safety in an insecure world. Cambridge: Polity.

Bulkeley, H. and Newell, P. (2010). Governing climate change. London: Routledge.

Cohen, D. (2010). Reaching out for resilience: exploring approaches to inclusion and diversity in the Transition movement. Unpublished MSc thesis, Centre for Human Ecology.

Connors, P. and McDonald, P. (2010). Transitioning communities: community, participation and the Transition Town movement. Community Development Journal. Advanced Access. [Online]. Retrieved on 17 August 2011 from: http://cdj.oxfordjournals.org/content/early/2010/02/25/cdj.bsq014.full.pdf.

Crow, G. and Allen, G. (1994). Community life: an introduction to local social relations. London: Harvester Wheatsheaf.

DECC (2009). The UK low carbon transition plan. [Online]. Retrieved on 17 August 2011 from: http:// www.decc.gov.uk/assets/decc/white\%20papers/uk\%20low\%20carbon\%20transition\%20plan\%20wp09/ 1_20090724153238_e_@@_lowcarbontransitionplan.pdf.

Defilipps, J., Fisher, R. and Shragge, E. (2006). Eeither romance nor regulation: re-evaluating community. International Journal of Urban and Regional Research 30 (3), pp. 673-689.

Devine-Wright, P. (2005). Local aspects of UK renewable energy development: exploring public benefits and policy implications. Local Environment 10 (1), pp. 57-69.

Guattari, F. (1995). Chaosmosis: an ethico-aesthic paradigm. Bloomington, IA: Indiana University Press.

Heiskanen, E., et al. (2010). Low-carbon communities as a context for individual behavioural change. Energy Policy 38, pp. 7586-7595.

Herbert, S. (2010). Reviews. Environment and Planning D: Society and Space 28, pp. 379-380.

Hinchcliffe, S. (1996). Helping the earth begins at home: the social construction of socio-environmental responsibilities. Global Environmental Change 6 (1), pp. 53-62.

Holmgren, D. (2011). Permaculture: principles and pathways beyond sustainability Hepburn. Victoria: Holmgren Design Services.

Hopkins, R. (2008). The transition handbook: from oil dependency to local resilience. Totnes: Green Books.

Irvine, S. (2009) Transitional demands. Red Pepper, 19 December, 2009

Johnson, S. (2000). Emergence: the connected lives of ants, brains, cities and software. London: Allen Lane.

Lichterman, P. (1995). Piecing together multicultural community: cultural differences in community building among grass-roots environmentalists. Social Problems 42 (4), pp. 513-534.

Mason, K. and Whitehead, M. (2011). Transition urbanism and the contested politics of ethical place making. Antipode. doi: 10.1111/j.1467-8330.2010.00868.x

Massey, D. (2007). World city. Cambridge: Polity.

Middlemiss, L. and Parrish, B. D. (2010). Building capacity for low-carbon communities: the role of grassroots initiatives. Energy Policy 38, pp. 7559-7566.

Mohan, J. (2011). Mapping the big society: perspectives from the third sector research centre, TSRC Working Paper 62, July, 2011

Mollison, B. (1988). Permaculture: a designers' manual Tagari. Tyalgum: NSW.

Morton, T. (2010). The mesh, the strange stranger and the beautiful soul. In: Mackay, R. (ed) Collapse VI: geo/ philosophy. Falmouth: Urbanonmic, pp. 265-293.

Phillis, Y. A. and Andriantiatsaholiniaina, L. A. (2001). Sustainability: an ill-defined concept and assessment using fuzzy logic. Ecological Economics 37 (3), pp. 435-456.

Seyfang, G. (2009). The new economics of sustainable consumption: seeds of change. Basingstoke: Palgrave MacMillan.

Shove, E. (2003). Comfort, cleanliness and convenience: the social organisation of normality. Oxford: Berg.

Smith, A. (2005). The alternative technology movement: an analysis of its framing and negotiation of technological development. Research in Human Ecology 12 (2), pp. 106-119.

Smith, A. (2011). The transition town network: a review of current evolutions and renaissance. Social Movement Studies 10 (1), pp. 99-105. 
Thaler, R. H. and Sunstein, C. R. (2009). Nudge: improving decisions about health, wealth and happiness. London: Penguin.

Toke, D. (2005). Community wind power in Europe and in the UK. Wind Engineering 29, pp. 301-308.

Toke, D., Breukers, S. and Wolsink, M. (2008). Wind power deployment outcomes: how can we account for the differences? Renewable and sustainable Energy Review 12 (4), pp. 1129-1147.

Tönnies, F. (1955). Community and association. London: Routledge.

Trapese Collective (2008) The rocky road to a real transition. [Online]. Retrieved on 10 December 2010 from. http://www.trapese.org/.

Walker, B. H. and Salt, D. (2006). Resilience thinking: sustaining ecosystems and people in a changing world. Washington D.C.: Island Press.

Walker, G. and Devine-Wright, P. (2008). Community renewable energy: what should it mean? Energy Policy 36, pp. 479-500.

Walker, G., et al. (2007). Harnessing community energies: explaining and evaluating community-based localism in renewable energy policy in the UK. Global Environmental Politics 7 (2), pp. 64-82.

Warren, C. R. and Birnie, R. V. (2009). Re-powering Scotland: wind farms and the 'energy or environment?' Debate. Scottish Geographical Journal 125 (2), pp. 97-126.

Warren, C. R. and McFadyen, M. (2010). Does community ownership affect public attitudes to wind energy? A case study from south-west Scotland. Land Use Policy 27 (2), pp. 204-213.

Williams, R. (1983). Community. In Keywords. London: Fontana.

Willmott, P. and Young, M. (1957). Family and class in a London suburb. London: Routledge. 